\title{
Manganese Phosphite in Coffee Defence against Hemileia vastatrix, the Coffee Rust Fungus: Biochemical and Molecular Analyses
}

\author{
Ana Cristina Andrade Monteiro ${ }^{1}$, Mário Lúcio Vilela de Resende ${ }^{1}$, Thaís Cainã Teixeira Valente ${ }^{1}$, \\ Pedro Martins Ribeiro Junior ${ }^{2}$, Vanessa Foresti Pereira ${ }^{1}$, Josineide Rodrigues da Costa ${ }^{1}$ and \\ Joyce Alves Goulart da Silva' \\ 1 Department of Plant Pathology, Federal University of Lavras, CEP 37200-000, Lavras, MG, Brazil \\ 2 Embrapa Semiárido, CEP 56302-970, Petrolina, PE, Brazil
}

\section{Keywords}

Coffea Arabica, enzymatic activity, gene expression, resistance elicitor, rust

\section{Correspondence}

M. L. V. de Resende, Department of Plant Pathology, Federal University of Lavras,

Lavras, MG, Brazil.

E-mail: mlucio@dfp.ufla.br

Received: May 5, 2016; accepted: September 12, 2016.

doi: $10.1111 /$ jph.12525

\begin{abstract}
Phosphites (Phi) are inorganic salts of phosphorous acid that have been used as resistance elicitors to activate mechanisms underlying plant defence. This study assessed the effectiveness of manganese phosphite (MnPhi) for the management of rust (Hemileia vastatrix) on coffee seedlings. The effect of this compound on the induction of resistance was also measured by the expression of defence-related genes such as POX (peroxidase), CAT (catalase), GLU ( $\beta$-1.3-glucanase) and $P A L$ (phenylalanine ammonia-lyase) and by the activity of defence enzymes such as ascorbate peroxidase (APX), superoxide dismutase (SOD) and polyphenol oxidase (PPO). Foliar sprayings of MnPhi on coffee seedlings provided $63 \%$ control of rust severity. This compound induced defence responses in seedlings with increased transcription of genes POX, CAT, GLU and PAL in non-inoculated plants and increased activity of APX, SOD and PPO enzymes in plants inoculated with $H$. vastatrix and in non-inoculated plants. It is suggested that MnPhi can induce resistance in coffee seedlings.
\end{abstract}

\section{Introduction}

Coffee cultivation is an important economical activity in Brazil, and the country is the major producer and exporter of coffee beans. Although this activity has growth potential, coffee farmers have faced problems due to crop susceptibility to diseases, which leads to reduction in yield and increasing production costs.

Coffee rust, caused by the fungus Hemileia vastatrix Berk and $\mathrm{Br}$, is the major coffee disease, occurring in almost all coffee-producing countries in the world (Rozo et al. 2012). The disease can cause a 35-50 per cent yield reduction, if no control action is taken (Silva et al. 2006). These losses are due to the formation of pustules on leaves, which reduce the photosynthetic area and lead to early leaf fall and drying of branches (Martins et al. 2004).

Most coffee cultivars in Brazil are susceptible to rust (Carvalho et al. 2012), and the disease is currently managed through the use of protectant and systemic fungicides including copper, triazoles and strobilurins (Zambolim 2016); however, given the harmful impact of these fungicides on the environment and the risk of emergence of resistant races for these compounds (Fernández-Ortuño et al. 2008), there is a pressing need for alternative coffee rust management measures.

Disease-resistant plants display elaborated signal networks that result in the expression of defence response (Daniel and Guest 2006). One of the first defence responses of a plant infected by a pathogen is the oxidative burst, characterized by rapid generation of reactive oxygen species (ROS) (Thatcher et al. 2005). Subsequently, the pathogen is confronted with hypersensitivity reaction, accumulation of phenolic compounds such as phytoalexins and induction of structural and biochemical barriers (Goellner and Conrath 2008; Silvar et al. 2008). 
Certain natural and synthetic compounds stimulate defence responses similarly to those observed in incompatible interactions (Daniel and Guest 2006). These compounds are known as resistance elicitors. Thus, using substances or organisms that induce resistance is an alternative to control plant diseases. Induced resistance is the activation of mechanisms underlying plant defence, which may be a local or systemic phenomenon and is effective against a broad range of pathogens including bacteria, fungi and viruses (van Loon et al. 1998).

Phosphite (Phi) is a chemical compound that has been used to induce defence responses in plants (Eshraghi et al. 2011). Phosphites are inorganic salts of phosphorous acid $\left(\mathrm{H}_{3} \mathrm{PO}_{3}\right)$ formulated with potassium, manganese, copper or zinc. These inorganic compounds can influence $\mathrm{pH}$ and redox homeostasis, hormone signalling and enzymes involved in stress response (Du Jardin 2015). In the United States, phosphites are registered for the control of oomycetes (King et al. 2010) while in Brazil they are considered foliar fertilizers and reduce disease severity in various crops such as onion (Wordell Filho and Stadnik 2006), papaya (Dianese et al. 2008, 2009), grapevine (Pereira et al. 2010, 2012), mango (Araujo et al. 2015), eucalyptus (Silva et al. 2013) and coffee (Nojosa et al. 2009; Dalio et al. 2012; Costa et al. 2014).

Studies suggest that Phi has a complex mode of action, including direct and indirect effects, on the pathogen and on the plant, respectively. Direct effect refers to the inhibition of pathogen growth and reduction or change in its metabolism (King et al. 2010). Indirect effect involves stimulation of plant defence mechanisms, such as increased production of phytoalexins and ROS, induction of pathogenesis-related proteins (PR) and strengthening of cell wall (Deliopoulos et al. 2010; Eshraghi et al. 2011; Pilbeam et al. $2011)$.

A balanced mineral nutrition may increase plant resistance to pathogens. Although Phi is considered a foliar fertilizer, it is not metabolized by plant cells and not used as source of phosphorus (Gómez-Merino and Trejo-Téllez 2015). However, some elements of these compounds may act as fertilizers, such as manganese in MnPhi (Dalio et al. 2012). Manganese is an essential nutrient for plants and necessary for important metabolic processes. It is also involved in the biosynthesis of soluble phenols and lignin, acting as a cofactor of key enzymes in plant defence, such as phenylalanine ammonia-lyase, and in the inhibition of exoenzymes such as pectin methylesterase, produced by certain fungi to degrade host cell walls. In addition, Mn-superoxide dismutase is activated by manganese, acting in ROS cleaning (Graham and Webb 1991; Marschner 2012).

Recent reports have demonstrated the effectiveness of products based on Phi for the management of coffee diseases. Nojosa et al. (2009) found reduction in severity of Phoma leaf spot on coffee seedlings sprayed with potassium phosphite, and Costa et al. (2014) found that MnPhi reduced severity of rust and cercosporiosis on coffee trees. It is also known that the standard resistance elicitor, acibenzolar-S-methyl (ASM), is effective in controlling coffee rust (Marchi et al. 2002; Guzzo et al. 2004) by inducing genes associated with systemic acquired resistance (SAR) (De Nardi et al. 2006; Guzzo et al. 2009). Thus, this study was conducted to assess the effectiveness of MnPhi compared with ASM, to control rust on coffee seedlings. In addition, we evaluated MnPhi effect as resistance elicitor by analysing the expression of defence-related genes (POX, CAT, GLU and PAL) and the activity of defence enzymes (APX, SOD and PPO).

\section{Material and Methods}

\section{Plant material}

Seeds of coffee cultivar Mundo Novo 379/19 were sown in trays containing washed sand for preparation of seedlings. After the first pair of true leaves had emerged, seedlings were transplanted in 0.50-L polyethylene bags containing soil, sand and commercial growing substrate for vegetables - Multiplant ${ }^{\circledR}$ (Terra do Paraíso, Brazil), in the proportion $2: 1: 1$ (v/v/v). Seedlings with four pairs of leaves were used to perform the experiments. Throughout the experimental period, the seedlings were kept in a glasshouse at the Department of Plant Pathology, Federal University of Lavras (UFLA), Minas Gerais, Brazil. The glasshouse used for these experiments was maintained at 25$32^{\circ} \mathrm{C}$ (day) and $17-24^{\circ} \mathrm{C}$ (night) with natural light. Plants were irrigated regularly and received additional fertilization with macro- and micronutrients according to technical recommendation for coffee seedlings (Guimarães et al. 1999).

\section{Inoculation}

Urediniospores of $H$. vastatrix were collected by scraping pustules from naturally infected coffee leaves, placed in microtubes and stored at room temperature protected from light for $48 \mathrm{~h}$. A suspension of $1 \times 10^{5}$ urediniospores $/ \mathrm{ml}$ water agar $(0.2 \% \mathrm{p} / \mathrm{v})$ containing Tween-20 (0.05\% v/v) was prepared for 
plant inoculation (Salustiano et al. 2008). The suspension was sprayed on the abaxial surface of leaves, and then, seedlings were placed in a humid chamber at $24 \pm 2{ }^{\circ} \mathrm{C}$ in the dark for $72 \mathrm{~h}$.

\section{Protection of coffee seedlings against rust}

This experiment was conducted to verify the MnPhi efficiency on the control of coffee rust, compared with a standard resistance inducer and control treatments. Seedlings were sprayed with the following treatments: MnPhi [Active $\mathrm{Mn}^{\circledR}\left(\begin{array}{lllll} & \\ & (51.0 \% & \mathrm{P}_{2} \mathrm{O}_{5} & \text { and } 9.7 \% & \mathrm{Mn}\end{array}\right)$ produced by Agrichem do Brazil SA, Brazil], dose $5.0 \mathrm{ml} / \mathrm{l}$; the resistance inducer acibenzolar-S-methyl - ASM (Bion ${ }^{\circledR}$ by Syngenta Crop Protection Ltd., Basel, Switzerland), dose $0.2 \mathrm{~g} / \mathrm{l}$, was used as a standard treatment; control plants were sprayed with water. Seven days after spraying, plants were inoculated with $H$. vastatrix.

Rust severity assessment started 40 days after inoculation, when the first symptoms of disease appeared. Six evaluations were performed using the diagrammatic scale proposed by Cunha et al. (2001) at 40, 55, $70,85,100$ and 115 days after inoculation. Then, the area under the disease severity progress curve (AUDSPC) was calculated according to Shaner and Finney (1977). The experiment was set in a complete randomized block design with four replications of seven plants each.

\section{qRT-PCR analyses}

After verifying that MnPhi is as efficient as ASM for the control of coffee rust, analyses of the expression of $P O X, C A T, G L U$ and PAL genes were performed to verify whether MnPhi induces increased expression of these genes, even in the absence of pathogen. Coffee seedlings were sprayed with MnPhi $(5.0 \mathrm{ml} / \mathrm{l})$ and water-sprayed plants were used as control. Plant materials for analyses were collected at 12, 24, 48 and $72 \mathrm{~h}$ after treatment application (haa). The first and second pairs of fully expanded leaves from the apex of each seedling were collected at each sampling time. Leaves were immediately frozen in liquid nitrogen and placed in a deep freezer at $-80^{\circ} \mathrm{C}$. The experiment was conducted in a complete randomized block design with three replications and four plants per replication per collection time.

Total RNA was extracted from plant tissues using the Pine Tree protocol described by Chang et al. (1993) and adapted for microextraction. To each microtube containing approximately $100 \mathrm{mg}$ of macerated leaves in liquid nitrogen was added $1 \mathrm{ml}$ of extraction buffer
[2\% CTAB (cetyltrimethylammonium bromide), 2\% PVP (polyvinylpyrrolidone), $100 \mathrm{~mm}$ Tris- $\mathrm{HCl}, 25 \mathrm{~mm}$ EDTA and $2 \mathrm{~m} \mathrm{NaCl}]$ and $20 \mu \mathrm{l}$ of $\beta$-mercaptoethanol. Homogenization was carried out by vortexing and the mixture was incubated for $20 \mathrm{~min}$ at $65^{\circ} \mathrm{C}$. Then, $1 \mathrm{ml}$ of chloroform: isoamyl alcohol (24:1) solution was added to each sample, which was stirred and centrifuged for $30 \mathrm{~min}$ at $12000 \times \boldsymbol{g}$ at $4^{\circ} \mathrm{C}$. The supernatant was transferred to a new tube to which the same volume of that solution was added, followed by homogenizing and centrifuging for $30 \mathrm{~min}$ at $12000 \times \mathrm{g}$ at $4^{\circ} \mathrm{C}$. The aqueous phase was then transferred to a new tube, and $10 \mathrm{~m}$ lithium chloride was added (25\% of the aqueous phase volume), followed by rapid inversion mixing. Samples were left overnight at $-20^{\circ} \mathrm{C}$ for precipitation and centrifuged for $30 \mathrm{~min}$ at $12000 \times g$ at $4^{\circ} \mathrm{C}$, and the supernatant was discarded. The pellet formed was washed twice with $1 \mathrm{ml}$ of $75 \%$ ethanol $(\mathrm{v} / \mathrm{v})$, followed by centrifugation for $10 \mathrm{~min}$ at $12000 \times \mathrm{g}$ at $4^{\circ} \mathrm{C}$. After washing, RNA solubilization was carried out. The pellet was resuspended in $20 \mu \mathrm{l}$ autoclaved Milli-Q water and stored in a deep freezer at $-80^{\circ} \mathrm{C}$. RNA integrity was visualized on $1.0 \%$ agarose gel stained with GelRed ${ }^{\mathrm{TM}}$ (Biotium, Fremont, CA, USA) and samples were quantified by NanoDrop $^{\mathrm{TM}} \quad$ Spectrophotometer ND-100 (Thermo Fisher Scientific, Wilmington, DE, USA).

Total RNA was treated with TURBO ${ }^{\text {тм }}$ DNase I (Ambion, Austin, TX, USA) according to the manufacturer's specifications. The absence of DNA was checked by a conventional PCR (negative control). Contaminated samples were retreated with TURBO ${ }^{\mathrm{TM}}$ DNase I to eliminate residual DNA contamination. RNA integrity was visualized on $1.0 \%$ agarose gel and samples were quantified by NanoDrop ${ }^{\mathrm{TM}}$.

The kit SuperScript ${ }^{\circledR}$ III First-Strand Synthesis SuperMix (Invitrogen, Carlsbad, CA, USA) was used for cDNA synthesis, following the manufacturer's suggested protocol. Samples were stored at $-20^{\circ} \mathrm{C}$ until use.

The qRT-PCR primers for the coffee genes $P O X$, $C A T, G L U$ and $P A L$ encoding, respectively, peroxidase, catalase, $\beta$-1.3-glucanase and phenylalanine ammonia-lyase enzymes, were designed using the PRIMER 3 software (Whitehead Institute for Biomedical Research, Cambridge, MA, USA) (Table 1). Primers were also designed to amplify polyubiquitin, alcohol dehydrogenase, actin 7, glyceraldehyde-3-phosphate dehydrogenase $(G A P D H)$, 60S ribosomal protein L7 and 14-3-3 genes, used as constitutive controls for coffee according to Barsalobres-Cavallari et al. (2009). After primer efficiency test, GAPDH and 14-3-3 primers were selected and checked their stability among treatment and collection times. 
Table 1 Primer sequences used for qRT-PCR analyses

\begin{tabular}{|c|c|c|c|}
\hline Genes & Primer sequences $\left(5^{\prime}-3^{\prime}\right)$ & Fragment size & Accession number \\
\hline \multirow[t]{2}{*}{ POX } & F: GAAGTGAAGTCTCGGCATCC & \multirow[t]{2}{*}{151} & \multirow[t]{2}{*}{ DQ124021.1 ${ }^{\mathrm{a}}$} \\
\hline & R: CAGGCAGTCTCCCCTCTTTT & & \\
\hline \multirow[t]{2}{*}{ CAT } & F: GCAGCTGGAAACTACCCTGA & \multirow[t]{2}{*}{194} & \multirow[t]{2}{*}{ DQ124022.1 $1^{\mathrm{a}}$} \\
\hline & R: AAGCCAAGCTGCTCATTCTC & & \\
\hline \multirow[t]{2}{*}{ GLU } & F: ATGGCGCTCAAAATTACCAG & \multirow[t]{2}{*}{244} & \multirow[t]{2}{*}{ DQ124030.1 ${ }^{\mathrm{a}}$} \\
\hline & R: ATTGGGGTATGGAAGCATGA & & \\
\hline \multirow[t]{2}{*}{ PAL } & F: GATGGGAAAGGGCACTGATA & \multirow[t]{2}{*}{223} & \multirow[t]{2}{*}{ AF218454. $1^{\mathrm{a}}$} \\
\hline & R: GATGCCAGAGTACCCCTGAA & & \\
\hline \multirow[t]{2}{*}{ GAPDH } & F: TTGAAGGGCGGTGCAAA & \multirow[t]{2}{*}{59} & \multirow[t]{2}{*}{ SGN-U347734 ${ }^{\mathrm{b}}$} \\
\hline & R: AACATGGGTGCATCCTTGCT & & \\
\hline \multirow[t]{2}{*}{$14-3-3$} & F: TGTGCTCTTTTAGCTTCCAAACG & \multirow[t]{2}{*}{75} & \multirow[t]{2}{*}{ SGN-U356404 ${ }^{\mathrm{b}}$} \\
\hline & R: CTTCACGAGACATATTGTCTTACTCAAA & & \\
\hline
\end{tabular}

${ }^{\mathrm{a} A c c e s s i o n}$ number according to GenBank; ${ }^{\mathrm{b}}$ Accession number according to SOL Genomics Network; (F) Sequence of forward primer; (R) Sequence of reverse primer.

Quantitative RT-PCR analyses were performed using ABI PRISM 7500 Real-Time PCR model (Applied Biosystems, Carlsbad, CA, USA) and SYBR Green detection system. Reaction conditions were as follows: $2 \mathrm{~min}$ at $50^{\circ} \mathrm{C}$ and $10 \mathrm{~min}$ at $95^{\circ} \mathrm{C}$ followed by 40 cycles of $15 \mathrm{~s}$ at $95^{\circ} \mathrm{C}$ and $1 \mathrm{~min}$ at $60^{\circ} \mathrm{C}$, ending with $15 \mathrm{~s}$ at $95^{\circ} \mathrm{C}$. For each reaction, $1.0 \mu \mathrm{l} \mathrm{cDNA}, 0.2 \mu \mathrm{l}$ of each primer and 5.0 $\mu$ l Power SYBR ${ }^{\circledR}$ Green PCR Master Mix with ROX (Invitrogen, USA) were used for a final volume of $10.0 \mu \mathrm{l}$ per sample. For each gene under study, the experiment was conducted using cDNA from three biological replicates with three technical replicates. Results were normalized using CT (Threshold Cycle) obtained by the expression of constitutive GAPDH and 14-3-3 genes. Quantification of gene expression was performed by the comparative CT method (Livak and Schmittgen 2001).

\section{Enzyme activity analyses}

After qRT-PCR analyses, activities of APX, SOD and PPO enzymes were performed to verify whether MnPhi provides increases in the activities of such defence enzymes in coffee plants with and without $H$. vastatrix inoculation. This test consisted of four treatments: coffee seedlings sprayed with MnPhi, with or without inoculation, and coffee seedlings sprayed with water, with or without inoculation. Treatments sprayings and pathogen inoculation (168 haa) were performed as previously described. Plant materials were collected at 24, 48, 72, 192, 216 and 240 haa. The first and second pairs of fully expanded leaves from the apex of each seedling were collected at each sampling time. Leaves were immediately frozen in liquid nitrogen and placed in a deep freezer at $-80^{\circ} \mathrm{C}$. The experiment was conducted in a randomized block design consisting of two treatments before inoculation and four treatments after $H$. vastatrix inoculation (168 haa), with three replications and experimental plots consisting of three plants for each collection time.

Plant extracts for determining SOD and APX activity were prepared by macerating $200 \mathrm{mg}$ samples of leaf tissue in liquid nitrogen in a mortar with $1 \%$ polyvinylpyrrolidone (PVP). The fine powder was homogenized in $100 \mathrm{~mm}$ potassium phosphate buffer at $\mathrm{pH} 7.8,0.1 \mathrm{~mm}$ EDTA and $10 \mathrm{~mm}$ ascorbic acid and then centrifuged at $13000 \times \boldsymbol{g}$ for $25 \mathrm{~min}$ at $4^{\circ} \mathrm{C}$. Supernatants were used for enzyme analyses (Biemelt et al. 1998).

Ascorbate peroxidase activity was determined by the Nakano and Asada method (1981). Twenty microlitres of the plant extract was added to $200 \mu \mathrm{l}$ of solution containing $100 \mathrm{~mm}$ potassium phosphate at $\mathrm{pH}$ 7.0, $0.5 \mathrm{~mm}$ ascorbic acid, $0.1 \mathrm{~mm}$ hydrogen peroxide and water. The activity was determined by the consumption of $\mathrm{H}_{2} \mathrm{O}_{2}$ at $290 \mathrm{~nm}$ for $1 \mathrm{~min}$ at $25^{\circ} \mathrm{C}$. The molar extinction coefficient of $1.4 / \mathrm{mm} / \mathrm{cm}$ was used to calculate APX activity.

Superoxide dismutase activity was assessed by the ability of the enzyme to inhibit photoreduction of nitroblue tetrazolium (NBT) (Giannopolitis and Ries 1977) in incubation medium consisting of $50 \mathrm{~mm}$ potassium phosphate at $\mathrm{pH} 7.8,14 \mathrm{~mm}$ methionine, $0.1 \mu \mathrm{M}$ EDTA, $75 \mu \mathrm{M}$ NBT, $2 \mu \mathrm{M}$ riboflavin and plant extract. After incubation for $7 \mathrm{~min}$ in a closed incubator with $30-\mathrm{W}$ fluorescent lamp, reading was performed at $560 \mathrm{~nm}$. One SOD unit was considered the amount of enzyme able to be inhibited by $50 \%$ NBT photoreduction under the assay conditions.

To obtain the extracts for enzymatic determination of PPO, leaf tissue was macerated as already described. 
The powder was homogenized in $30 \mathrm{~mm}$ potassium phosphate buffer at pH 7.0, 0.1 mM EDTA and water. After centrifugation at $13000 \times \mathfrak{g}$ for $25 \mathrm{~min}$ at $4^{\circ} \mathrm{C}$, the supernatant was used for the determination of enzyme activity. Polyphenol oxidase activity was determined according to the method by Kar and Mishra (1976). Twenty microlitres of the plant extract was added to $200 \mu \mathrm{l}$ of solution containing $70 \mathrm{~mm}$ potassium phosphate at $\mathrm{pH} 7.0$ and $20 \mathrm{~mm}$ catechol. After incubation at $30^{\circ} \mathrm{C}$ for $10 \mathrm{~min}$, absorbance was measured at $410 \mathrm{~nm}$. The molar extinction coefficient of $1.235 / \mathrm{mm} / \mathrm{cm}$ was used to calculate PPO activity.

Total protein of each plant extract was measured according to Bradford (1976) using a standard curve of bovine serum albumin.

\section{Data analyses}

Data were subjected to analysis of variance (ANOvA) and mean separation test using the Sisvar statistical analysis software (Ferreira 2011). To examine the difference among treatments, Scott-Knott test at $\mathrm{P}<0.05$ was carried out. The Scott-Knott test is a powerful clustering method favoured over other pairwise multiple comparison tests due to the absence of ambiguity among groups (Scott and Knott 1974).

\section{Results}

Protection of coffee seedlings against rust

Resistance-inducing treatments MnPhi and ASM significantly reduced rust severity compared with the water-sprayed treatment (control). MnPhi and ASM treatments reduced rust severity up to 63 and 50\% in relation to the control, respectively (Table 2 ).

\section{Analyses of expression of $P O X, C A T, G L U$ and $P A L$ genes}

Molecular analyses to evaluate relative genes expression showed that MnPhi induced the expression of

Table 2 Effects of treatments on the area under the disease severity progress curve (AUDSPC) of coffee seedlings and percentage of disease control compared to the control treatment

\begin{tabular}{lll}
\hline Treatment & AUDSPC* & Control (\%) \\
\hline Manganese phosphite & $18.6 \mathrm{a}$ & 63.0 \\
Acibenzolar-S-methyl & $25.1 \mathrm{a}$ & 50.0 \\
Control (water) & $50.2 \mathrm{~b}$ & - \\
\hline
\end{tabular}

*Treatments with same letter do not differ by the Scott-Knott test, at a $P$ value of 0.05 .
POX, CAT, GLU and PAL genes. High level of expression was detected at 24 haa, differing from the other time points at $\mathrm{P}<0.05$ (Fig. 1). At 24 haa, the relative expressions of $P O X, C A T, G L U$ and $P A L$ genes were, respectively, 9-, 12-, 33- and 2.5-fold higher than the control treatment, which corresponds to the dashed line in Fig. 1. The expression levels of CAT and $P A L$ genes were not statistically different at 12,48 and 72 haa, and expression levels at these times were similar or inferior to the control (water sprayed). However, expression of $P O X$ at 12 and 48 haa and GLU at 48 haa showed significant increase compared with the control (Fig. 1).

\section{Activities of APX, SOD and PPO enzymes}

Biochemical analyses showed that MnPhi provided increased activity of APX, SOD and PPO enzymes in coffee seedlings with or without $H$. vatatrix inoculation. The activity of APX in MnPhi-sprayed plants was significantly different from the water-sprayed plants (control) at 24, 48 and 72 haa (Fig. 2a). At these time points, MnPhi induced 35-48 per cent increase in APX activity compared with the control treatment. At 192 haa, there was no difference between treatments. However, at 216 haa, coffee plants sprayed with MnPhi showed $78 \%$ higher activity of APX than control plants, differing from other treatments. Significant APX activity was also observed in plants treated with MnPhi and inoculated with $H$. vastatrix at 240 haa, which was $21 \%$ higher than control plants inoculated (Fig. 2a).

Superoxide dismutase activity showed non-significant difference when comparing the MnPhi and the control treatments before inoculation with $H$. vastatrix (Fig. 2b). At 192 haa, the control and MnPhi sprayed and inoculated with $H$. vastatrix treatments showed significant higher SOD activity $(\mathrm{P}<0.05)$ than the non-inoculated treatments. At this time point, MnPhi spraying followed by inoculation increased SOD activity by $55 \%$, compared with the control inoculated with $H$. vastatrix, and increased by $288 \%$, compared with the MnPhi spraying without inoculation. At 216 and 240 haa, there was no difference between treatments (Fig. 2b).

Regarding PPO, MnPhi-treated plants induced significantly $42 \%$ higher enzyme activity at 48 haa than water-sprayed plants (control). There was no difference between treatments at 24 and 72 haa (Fig. 2c). MnPhi-treated seedlings, either inoculated or not, showed significantly higher PPO activity than inoculated or non-inoculated water-sprayed seedlings, among 66 and $133 \%$, at 192 and 216 haa. At 

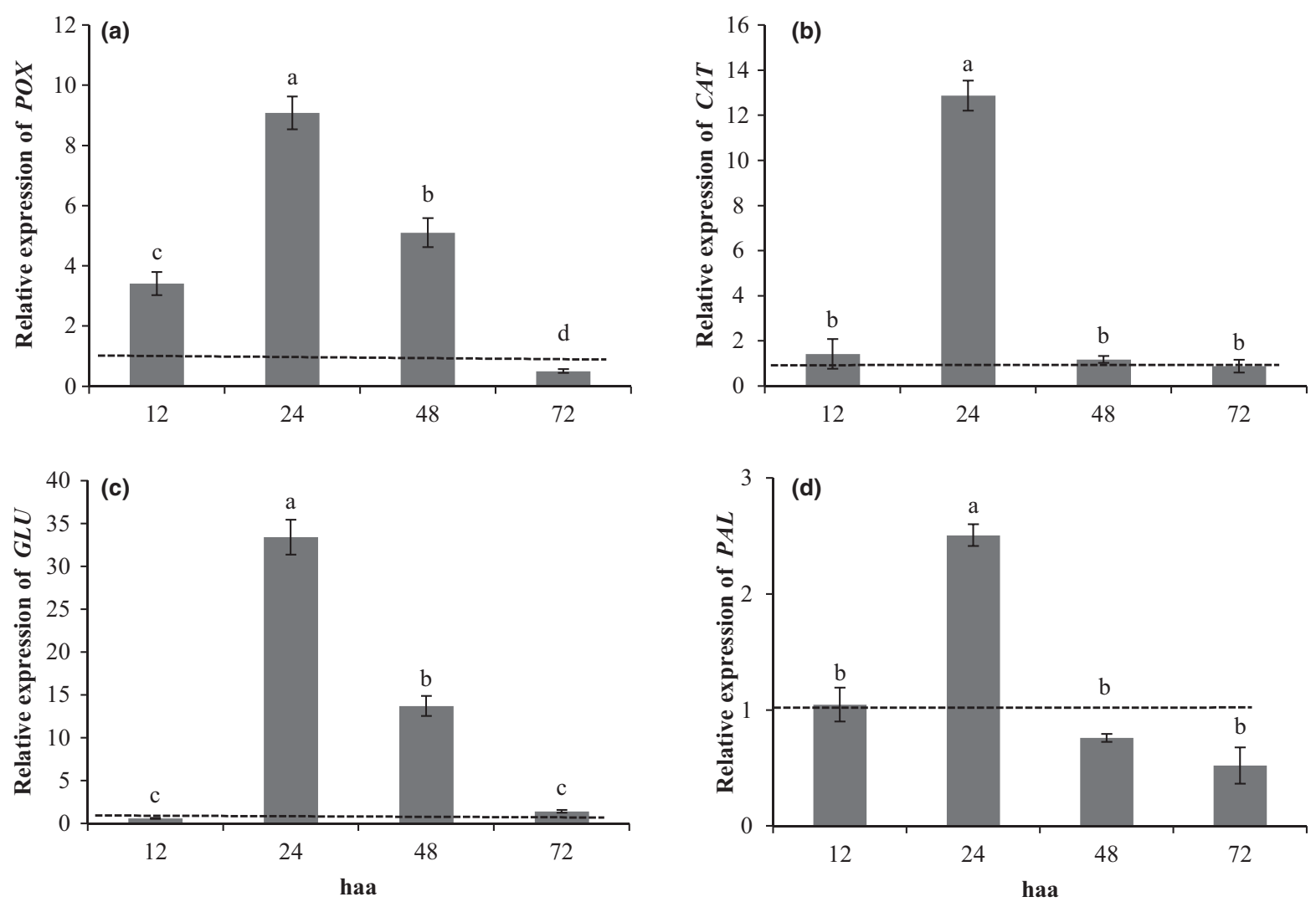

Fig. 1 Relative expression of POX (a) CAT (b), GLU (c) and PAL (d) genes in leaves of Coffea arabica seedlings after application of manganese phosphite. haa, hours after application. For each time point, the relative expression of each gene represents the transcript accumulation rate in relation to the control, which corresponds to the dashed line. GAPDH and 14-3-3 genes were used as constitutive controls. Error bars represent the standard error of the mean of three replicates. Bars followed by different letters are statistically different by the Scott-Knott test $(P \leq 0.05)$.

240 haa, plants sprayed with MnPhi and water and inoculated with $H$. vastatrix differed from treatments without inoculation. MnPhi-treated plants and inoculated with $H$. vastatrix showed $261 \%$ higher activity of PPO than control plants without inoculation (Fig. 2c).

\section{Discussion}

The effect of MnPhi on the interaction between coffee seedlings and H. vastatrix was investigated. Foliar spraying of MnPhi on coffee seedlings reduced the severity of rust and activated defence responses. MnPhi induced increased transcription of $P O X, C A T$, $G L U$ and $P A L$ genes in non-inoculated plants and provided increased activity of defence enzymes (APX, SOD and PPO) in inoculated and non-inoculated plants.

There are many reports of the use of Phi for controlling plant diseases caused by oomycetes (Jackson et al. 2000; Daniel and Guest 2006; Eshraghi et al. 2011; Lobato et al. 2011; Machinandiarena et al.
2012). Although $H$. vastatrix is a basidiomycete, studies have demonstrated the efficacy of phosphite-based products to control rust in coffee plantations (Dalio et al. 2012). Furthermore, Costa et al. (2014) demonstrated that MnPhi reduced rust severity by $62 \%$ under field conditions. This glasshouse study showed MnPhi is as effective as the standard elicitor ASM, by reducing the severity of coffee rust up to $63 \%$.

Studies show that phosphites also act indirectly by inducing resistance in plants (Deliopoulos et al. 2010; Eshraghi et al. 2011; Pilbeam et al. 2011; Lim et al. 2013). Furthermore, manganese present in MnPhi is involved in important metabolic processes such as biosynthesis of soluble phenols and lignin, being a cofactor of phenylalanine ammonia-lyase and superoxide dismutase (Graham and Webb 1991; Marschner 2012). Therefore, the micronutrient manganese in MnPhi possibly contributed to eliciting resistance in coffee plants by inducing the expression of defence genes such as $P A L$, increasing the activity of enzymes such as SOD. 


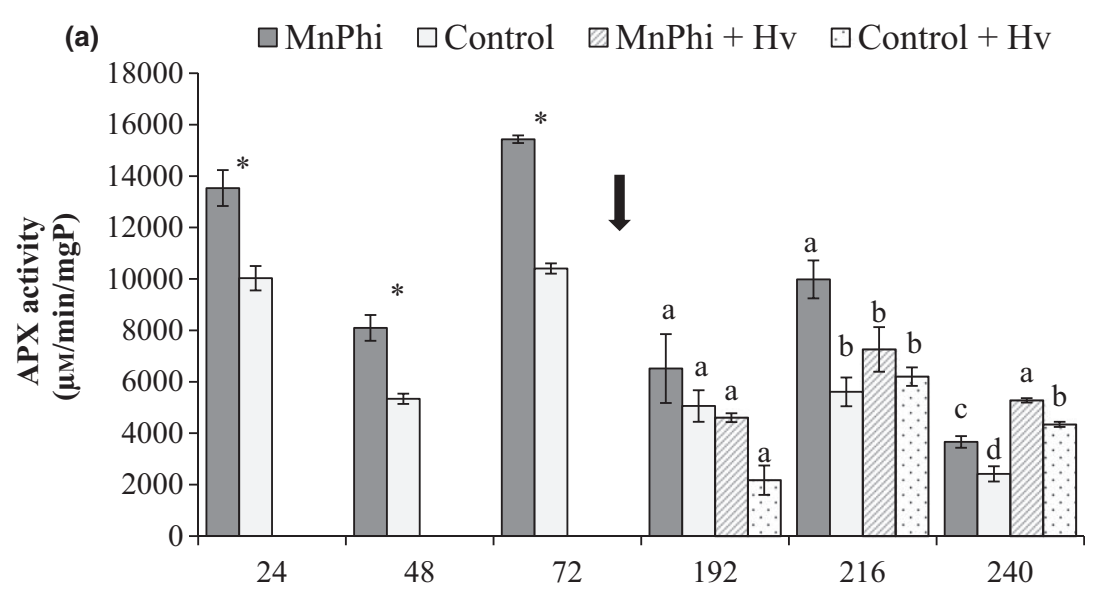

Fig. 2 Activities of ascorbate peroxidase (a), superoxide dismutase (b) and polyphenol oxidase (c) enzymes in leaves of Coffea arabica seedlings. Plants were sprayed with manganese phosphite (MnPhi) and controls sprayed with water. Arrows indicate inoculation with Hemileia vastatrix (Hv) at $168 \mathrm{~h}$ after application of treatments (haa). Error bars represent the standard error of the mean of three replicates. ns, not significant; *significant by Ftest at each time point. For each time point, bars followed by different letters are statistically different by the Scott-Knott test
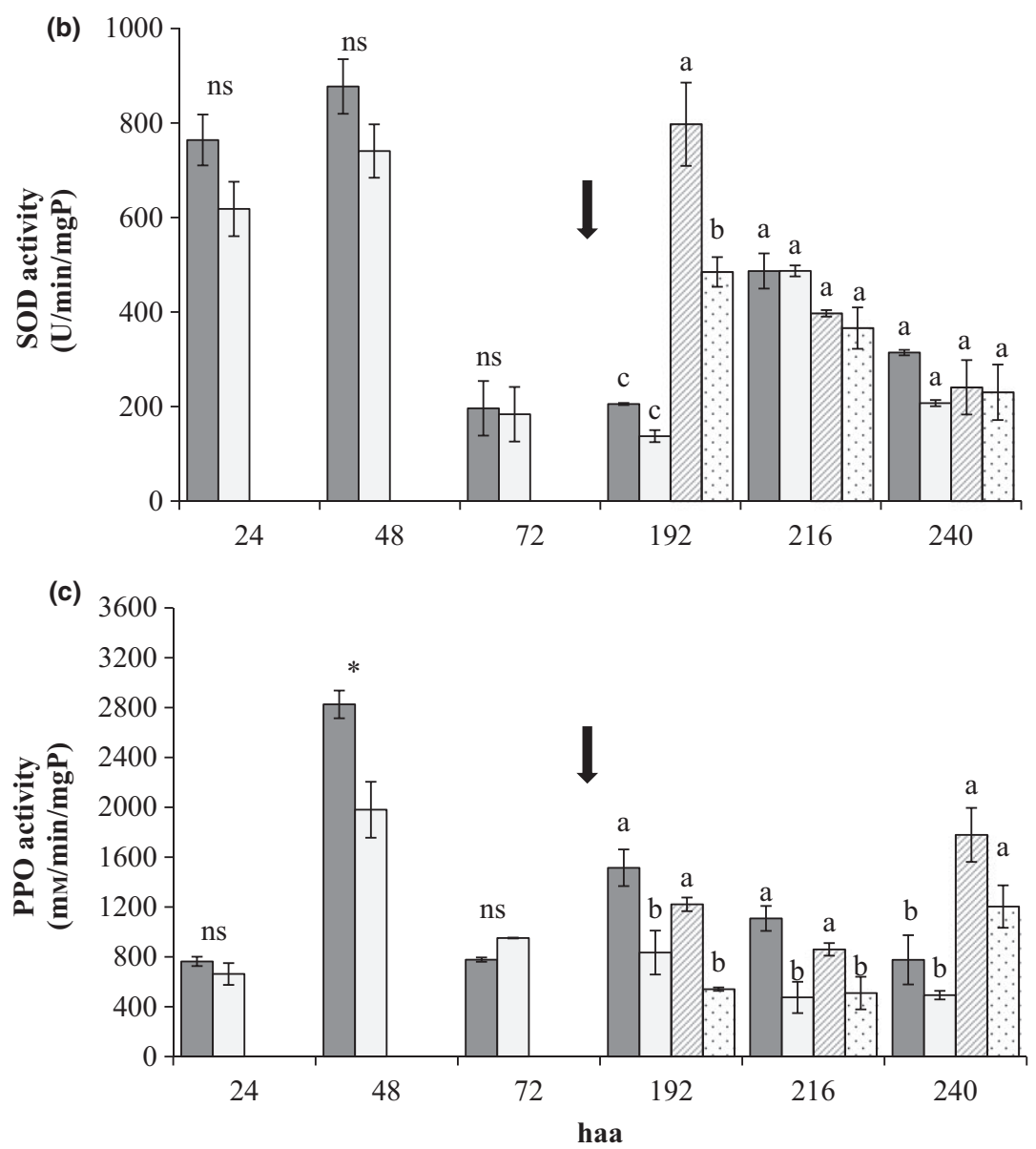

Some authors reported that Phi induces resistance in plants via oxidative burst, which consists of a rapid accumulation of ROS, followed by increased transcription of defence genes, including those of PR proteins (Goellner and Conrath 2008; Eshraghi et al. 2011; Machinandiarena et al. 2012; Lim et al. 2013).
Reactive oxygen species normally occur in cellular metabolism, but when accumulated in high amounts they become toxic to the cell. Plants under stress often use a complex antioxidant defence system consisting of antioxidants and a diverse array of enzymes, such as superoxide dismutase, catalase, peroxidase, glutathione reductase and APX. These enzymes clean 
ROS and protect cells from oxidative damage (Hossain and Uddin 2011). Fernandes et al. (2014) found increased activity in SOD, CAT and APX enzymes in coffee seedlings after MnPhi spraying in the absence of pathogen. The current study showed that MnPhi induced increase in SOD and APX activity in leaves of coffee seedlings after infection with $H$. vastatrix. Furthermore, increased transcription levels of $P O X$ and $C A T$ genes also indicated their possible action in ROS cleaning.

$\beta$-1.3-glucanase, phenylalanine ammonia-lyase and polyphenol oxidase enzymes are important in plant defence against pathogens. $\beta$-1.3-glucanase is a PR protein with antimicrobial activity, as it is able to hydrolyse glucans in fungal cell walls (Durrant and Dong 2004). Phenylalanine ammonia-lyase is a key enzyme in the phenylpropanoid pathway which leads to the formation of lignin and phenolic compounds (Raes et al. 2003). Polyphenol oxidase can oxidize phenolics into more toxic compounds, thereby increasing the degree of resistance to infection (Pourcel et al. 2007). In this study, coffee seedlings sprayed with MnPhi showed higher PPO activity and increased transcript levels of GLU and PAL genes that possibly translated into their respective enzymes. This fact certainly allowed for greater defence against coffee rust.

Immediately after inoculation with $H$. vastatrix, the fungus develops various specialized structures for infection. The literature shows that germination of urediniospores ceases between 8 and $24 \mathrm{~h}$ after inoculation (hai) and at the same time appressorium formation occurs. Generally, the initial formation of penetration hyphae occurs by 17 hai and the haustorium is observed between 36 and 48 hai (Silva et al. 2008; Diniz et al. 2012). In this work, it was observed that coffee seedlings sprayed with MnPhi and inoculated with $H$. vastatrix presented high SOD activity at 24 hai (192 haa), PPO at 24 and 48 hai (192 and 216 haa) and APX at 72 hai (240 haa). By comparing the infection process of the pathogen and the enzymatic activity here described, an oxidative burst certainly occurred in leaves of coffee seedlings at early stages of infection.

After treatment with Phi, responses of susceptible plants eventually become similar to those of plants naturally resistant to certain pathogens (Daniel and Guest 2006). Studies have shown that resistance to $H$. vastatrix in a number of coffee genotypes is expressed by a large release of hydrogen peroxide at 39 hai and a rapid, localized death of plant cells associated with fungal growth at 48 hai, as well as increased phenolic compounds and activities of defence enzymes at 24, 48, 72 and 96 hai (Silva et al. 2002, 2008; Guerra-Guimarães et al. 2009; Ramiro et al. 2009). During an incompatible interaction between coffee plants and $H$. vastatrix, Ramiro et al. (2009) found high generation of hydrogen peroxide and increased transcription of genes encoding PR proteins at $39 \mathrm{~h}$ after pathogen inoculation, while Silva et al. (2002, 2008) observed localized cell death at 48 hai, phenolic compound accumulation and increased activity of phenylalanine ammonia-lyase at 48 and 120 hai and increased peroxidase activity at 24 and 120 hai. GuerraGuimarães et al. (2009) reported an increase in chitinase activity at 24 and 72 hai. This study demonstrated that MnPhi induced the expression of defence genes POX, CAT, GLU and PAL at 24 haa. Furthermore, MnPhi provided increased activity of APX, SOD and PPO enzymes.

Silva et al. (2008) demonstrated the occurrence of two peaks of peroxidase activity during the incompatible interaction between coffee plants and $H$. vastatrix. The first peak occurs before or at the beginning of cell death, suggesting peroxidase involvement in fungal action. The second peak can be related to lignification of host tissue, which occurs around 5-7 days after inoculation. Analysis of $P O X$ gene expression induced by MnPhi in coffee showed increased transcript levels at 12-48 haa, with the highest level at 24 haa. It can be inferred that this increase in $P O X$ gene transcripts is related to cleaning of ROS. Although the evaluation of transcript levels was carried out only until 3 days after MnPhi application, it can also be inferred that the phenylpropanoid pathway was activated because of increased PAL gene transcripts and PPO enzyme activity.

The results of this study show that MnPhi reduces the severity of rust in coffee seedlings. Furthermore, they provide evidence that this compound induces transcription of defence genes ( $P O X, C A T, G L U$ and $P A L)$ and increase the activity of clean-up enzymes after oxidative stress (APX, SOD and PPO), suggesting that MnPhi is a promising alternative for the management of coffee diseases.

\section{Acknowledgements}

The authors thank Professor Luciano Vilela Paiva for allowing the use of the Central Laboratory of Molecular Biology (LCBM) at the Federal University of Lavras (UFLA), and the National Council for Scientific and Technological Development (CNPq), the Foundation for Research Support of the State of Minas Gerais (FAPEMIG) and the National Institute for Coffee 
Science and Technology (INCT- CAFÉ) for funding this study.

\section{References}

Araujo L, Bispo WMS, Rios VS, Fernandes SA, Rodrigues FA. (2015) Induction of the phenylpropanoid pathway by acibenzolar-smethyl and potassium phosphite increases mango resistance to Ceratocystis fimbriata infection. Plant Dis 99:447-459.

Barsalobres-Cavallari CF, Severino FE, Maluf MP, Maia IG. (2009) Identification of suitable internal control genes for expression studies in Coffea arabica under different experimental conditions. BMC Mol Biol 10:1.

Biemelt S, Keetman U, Albrecht G. (1998) Re-aeration following hypoxia or anoxia leads to activation of the antioxidative defense system in roots of wheat seedlings. Plant Physiol 116:651-658.

Bradford MM. (1976) A rapid and sensitive method for the quantification of microgram quantities of protein utilizing the principle of protein-dye binding. Anal Biochem 72:248-254.

Carvalho VL, Cunha RL, Silva NRN. (2012) Alternativas de controle de doenças do cafeeiro. Coffee Sci 7:42-49.

Chang S, Puryear J, Cairney J. (1993) A simple and efficient method for isolating RNA from pine trees. Plant Mol Biol Rep 11:113-116.

Costa BHG, Resende MLV, Ribeiro Júnior PM, Mathioni SM, Pádua MA, Silva Júnior MB. (2014) Suppression of rust and brown eye spot diseases on coffee by phosphites and by-products of coffee and citrus industries. J Phytopathol 162:635-642.

Cunha RL, Pozza EA, Dias WP, Barretti PB. (2001) Desenvolvimento e validação de uma escala diagramática para avaliar a severidade da ferrugem (Hemileia vastatrix) do cafeeiro. In: Anais do II, Simpósio Brasileiro de Pesquisa dos Cafés do Brasil. Resumos Expandidos. Vitória, Brazil, SBICAFE, pp 1101-1108.

Dalio RJD, Ribeiro Júnior PM, Resende MLV, Silva AC, Blummer S, Pereira VF, Osswald W, Pascholati SF. (2012) O triplo modo de ação dos fosfitos no controle de doenças de plantas. Revisão Anual de Patologia de Plantas 20:206-243.

Daniel R, Guest D. (2006) Defence responses induced by potassium phosphonate in Phytophthora palmivora-challenged Arabidopsis thaliana. Physiol Mol Plant Pathol 67:194-201.

De Nardi B, Dreos R, Del Terra L et al. (2006) Differential responses of Coffea arabica L. leaves and roots to chemically induced systemic acquired resistance. Genome 49:1594-1605.

Deliopoulos T, Kettlewell PS, Hare MC. (2010) Fungal disease suppression by inorganic salts: a review. Crop Prot 29:1059-1075.
Dianese AC, Blum LEB, Dutra JB, Lopes LF, Sena MC, Freitas LF. (2008) Avaliação do efeito de fosfitos na redução da varíola (Asperisporium caricae) do mamoeiro (Carica papaya). Rev Bras Frutic 30:834-837.

Dianese AC, Blum LEB, Dutra JB, Lopes LF. (2009)

Aplicação de fosfito de potássio, cálcio ou magnésio para a redução da podridão-do-pé do mamoeiro em casa de vegetação. Ciênc Rural 39:2309-2314.

Diniz I, Talhinhas P, Azinheira HG, Varzea V, Medeira C, Maia I, Petitot AS, Nicole M, Fernandez D, Silva MD. (2012) Cellular and molecular analyses of coffee resistance to Hemileia vastatrix and nonhost resistance to Uromyces vignae in the resistance-donor genotype HDT832/2. Eur J Plant Pathol 133:141-157.

Du Jardin P. (2015) Plant biostimulants: definition, concept, main categories and regulation. Sci Hortic 196:314.

Durrant WE, Dong X. (2004) Systemic acquired resistance. Annu Rev Phytopathol 42:185-209.

Eshraghi L, Anderson J, Aryamanesh N, Shearer B, McComb J, Hardy GES, O'Brien PA. (2011) Phosphite primed defence responses and enhanced expression of defence genes in Arabidopsis thaliana infected with Phytophthora cinnamomi. Plant Pathol 60:1086-1095.

Fernandes LHM, Silveira HRO, Souza KRD, Resende MLV, Alves JD. (2014) Inductors of resistance and their role in photosynthesis and antioxidant system activity of coffee seedlings. Am J Plant Sci 5:3710-3716.

Fernández-Ortuño D, Torés JA, Vicente A, Perez-García A. (2008) Mechanisms of resistance to QoI fungicides in phytopathogenic fungi. Inter Microbiol 11:1-9.

Ferreira DF. (2011) Sisvar: a computer statistical analysis system. Ciênc Agrotec 35:1039-1042.

Giannopolitis CN, Ries SK. (1977) Superoxide dismutase I. Occurrence in higher plants. Plant Physiol 59:309-314.

Goellner K, Conrath U. (2008) Priming: it's all the world to induced disease resistance. Eur J Plant Pathol 121:233-242.

Gómez-Merino FC, Trejo-Téllez LI. (2015) Biostimulant activity of phosphite in horticulture. Sci Hortic 196:8290.

Graham DR, Webb MJ. (1991) Micronutrients and disease resistance and tolerance in plants. In: Mortvedt J. J., Cox F. R., Shuman L. M., Welch R. M. (eds) Micronutrients in Agriculture, 2nd edn. Madison, Wisconsin, USA, Soil Science Society of America Inc, pp 329-370.

Guerra-Guimarães L, Silva MC, Struck C, Loureiro A, Nicole M, Rodrigues CJ, Ricardo CPP. (2009) Chitinases of Coffea arabica genotypes resistant to orange rust Hemileia vastatrix L. Biol Plant 53:702-706.

Guimarães PTG, Garcia AWR, Venegas VHA et al. (1999) Cafeeiro. In: Ribeiro AC, Guimarães PTG, Veneooga VHA. (eds) Recomendações para uso de corretivos e fertilizantes em Minas Gerais: $5^{\mathrm{a}}$ aproximação. Viçosa, MG, Brazil, CFSEMG, pp 289-302. 
Guzzo SD, Harakava R, Lucon CMM, Tsai SM. (2004) Resistência sistêmica adquirida em cafeeiro contra Hemileia vastatrix e indução local e sistêmica de quitinases e $\beta$-1,3-glucanases por acibenzolar-S-metil. Summa Phytopathol 30:376-381.

Guzzo SD, Harakava R, Tsai SM. (2009) Identification of coffee genes expressed during systemic acquired resistance and incompatible interaction with Hemileia vastatrix. J Phytopathol 157:625-638.

Hossain MA, Uddin SN. (2011) Mechanisms of waterlogging tolerance in wheat: morphological and metabolic adaptations under hypoxia or anoxia. Aust J Crop Sci 5:1094-1101.

Jackson TJ, Burgess T, Colquhoun I, Hardy GES. (2000) Action of the fungicide phosphite on Eucalyptus marginata inoculated with Phytophthora cinnamomi. Plant Pathol 49:147-154.

Kar M, Mishra D. (1976) Catalase, peroxidase, and polyphenoloxidase activities during rice leaf senescence. Plant Physiol 57:315-319.

King M, Reeve W, Van der Hoek MB, Williams N, McComb J, O'Brien PA, Hardy GE. (2010) Defining the phosphite-regulated transcriptome of the plant pathogen Phytophthora cinnamomi. Mol Genet Genomics 284:425435.

Lim S, Borza T, Peters RD, Coffin RH, Al-Mughrabi KI, Pinto DM, Wang-Pruski G. (2013) Proteomics analysis suggests broad functional changes in potato leaves triggered by phosphites and a complex indirect mode of action against Phytophthora infestans. J Proteomics 93:207-223.

Livak KJ, Schmittgen TD. (2001) Analysis of relative gene expression data using real-time quantitative PCR and the 2 (-Delta Delta C(T)) method. Methods 25:402-408. Lobato MC, Machinandiarena MF, Tambascio C, Dosio GAA, Caldiz DO, Daleo GR, Andreu AB, Olivieri FP. (2011) Effect of foliar applications of phosphite on postharvest potato tubers. Eur J Plant Pathol 130:155-163. van Loon LC, Bakker P, Pieterse CMJ. (1998) Systemic resistance induced by rhizosphere bacteria. Annu Rev Phytopathol 36:453-483.

Machinandiarena MF, Lobato MC, Feldman ML, Daleo GR, Andreu AB. (2012) Potassium phosphite primes defense responses in potato against Phytophthora infestans. J Plant Physiol 169:1417-1424.

Marchi CE, Borges MF, Resende MLV. (2002) Proteção induzida por benzotiadiazole contra a ferrugem-alaranjada (Hemileia vastatrix) em cafeeiro. Ciênc Agrotec 26:1103-1106.

Marschner H. (2012) Marschner's Mineral Nutrition of Higher Plants, 3rd edn. London, Academic Press, p 651.

Martins M, Mendes ANG, Alvarenga MIN. (2004) Incidência de pragas e doenças em agroecossistemas de café orgânico de agricultores familiares em Poço Fundo, MG. Ciênc Agrotec 28:1306-1313.
Nakano Y, Asada K. (1981) Hydrogen peroxide is scavenged by ascorbato-specific peroxidase in spinach chloroplasts. Plant Cell Physiol 22:867-880.

Nojosa GBA, Resende MLV, Barguil BM, Moraes SRG, Vilas Boas CH. (2009) Efeito de indutores de resistência em cafeeiro contra mancha de Phoma. Summa Phytopathol 35:60-62.

Pereira VF, Resende MLV, Monteiro ACA, Ribeiro Júnior PM, Regina MA, Medeiros FCL. (2010) Produtos alternativos na proteção da videira contra o míldio. Pesq Agropec Bras 45:25-31.

Pereira VF, Resende MLV, Ribeiro Júnior PM, Regina MA, Mota RV, Vitorino LRR. (2012) Fosfito de potássio no controle do míldio da videira e características físicoquímicas de uvas Merlot. Pesq Agropec Bras 47:15811588.

Pilbeam RA, Howard K, Shearer BL, Hardy G. (2011) Phosphite stimulated histological responses of Eucalyptus marginata to infection by Phytophthora cinnamomi. Trees Struct Funct 25:1121-1131.

Pourcel L, Routaboul JM, Cheynier V, Lepiniec L, Debeaujon I. (2007) Flavonoid oxidation in plants: from biochemical properties to physiological functions. Trends Plant Sci 12:29-36.

Raes J, Rohde A, Christensen JH, Peer YV, Boerjan W. (2003) Genome-wide characterization of the lignification toolbox in Arabidopsis. Plant Physiol 133:051-1071.

Ramiro DA, Escoute J, Petitot AS, Nicole M, Maluf MP, Fernandez D. (2009) Biphasic haustorial differentiation of coffee rust (Hemileia vastatrix race II) associated with defence responses in resistant and susceptible coffee cultivars. Plant Pathol 58:944-955.

Rozo Y, Escobar C, Gaitan A, Cristancho M. (2012) Aggressiveness and genetic diversity of Hemileia vastatrix during an epidemic in Colombia. J Phytopathol 160:732-740.

Salustiano M, Pozza EA, Ferraz A, Botelho A, Alves E. (2008) Variability in ten populations of Hemileia vastatrix for germination and germinative tube length under four temperatures. Ciênc Agrotec 32:1651-1656.

Scott AJ, Knott M. (1974) A cluster analysis method for grouping means in the analysis of variance. Biometrics 30:507-512.

Shaner G, Finney RF. (1977) The effect of nitrogen fertilization on the expression of slow-mildewing resistance in knox wheat. Phytopathol 67:1051-1056.

Silva MC, Nicole M, Guerra-Guimaraes L, Rodrigues CJ. (2002) Hypersensitive cell death and post-haustorial defence responses arrest the orange rust (Hemileia vastatrix) growth in resistant coffee leaves. Physiol Mol Plant Pathol 60:169-183.

Silva MC, Várzea V, Guerra-Guimarães L, Azinheira HG, Fernandez D, Petitot A-S, Bertrand B, Lashermes P, Nicole M, (2006) Coffee resistance to the main diseases: leaf rust and coffee berry disease. Braz J Plant Physiol 18:119-147. 
Silva MC, Guerra-Guimaraes L, Loureiro A, Nicole MR. (2008) Involvement of peroxidases in the coffee resistance to orange rust (Hemileia vastatrix). Physiol Mol Plant Pathol 72:29-38.

Silva AC, Resende MLV, Souza PE, Silva NCN, Silva MB Jr, Vitorino LRR. (2013) Coffee-leaf extract and phosphites on the curative control of powdery mildew in eucalyptus mini-stumps. For Path 43:297-305.

Silvar C, Merino F, Diaz J. (2008) Differential activation of defense-related genes in susceptible and resistant pepper cultivars infected with Phytophthora capsici. J Plant Physiol 165:1120-1124.

Thatcher LF, Anderson JP, Singh KB. (2005) Plant defence responses: what have we learnt from Arabidopsis? Funct Plant Biol 32:1-19.

Wordell Filho JA, Stadnik MJ. (2006) Controle da mancha acinzentada da cebola e seu impacto sobre a qualidade de mudas. Hortic Bras 24:437-441.

Zambolim L. (2016) Current status and management of coffee leaf rust in Brazil. Trop plant pathol 41:1-8. 